\title{
Public-Private Partnership Arrangement in In-Situ Housing for Slum Rehabilitation in Yenagoa, Bayelsa State, Nigeria
}

\author{
A. F. Ebakpa, A. E. Gobo, S. A. Ngah", T. K. S. Abam \\ Institute of Geosciences and Space Technology, Rivers State University, Port Harcourt, Nigeria \\ Email: ${ }^{\star}$ gahsab@yahoo.com
}

How to cite this paper: Ebakpa, A.F., Gobo, A.E., Ngah, S.A. and Abam, T.K.S. (2017) Public-Private Partnership Arrangement in In-Situ Housing for Slum Rehabilitation in Yenagoa, Bayelsa State, Nigeria. Journal of Environmental Protection, 8, 1530-1540.

https://doi.org/10.4236/jep.2017.812094

Received: October 15, 2017

Accepted: November 26, 2017

Published: November 29, 2017

Copyright ( 2017 by authors and Scientific Research Publishing Inc. This work is licensed under the Creative Commons Attribution International License (CC BY 4.0).

http://creativecommons.org/licenses/by/4.0/

\begin{abstract}
The provision of decent accommodation is a major challenge to government in the developing nations. It is a common phenomenon in the urban centres of the developing nations where most houses are in deplorable conditions. The houses are overcrowded with little or no air space between them. There is no basic sanitation in the urban centres as they lack flush toilet, some of the few available flush toilets are piped into seasonal streams, most houses lack defined kitchen areas and healthy sewage disposal method. The cities lack good access roads and functional drainage system with a common practice of environmentally-unfriendly solid waste management methods that create various health challenges to urban dwellers. The aim of the study is to show how in-situ Housing method of slum rehabilitation can be applied through Public/Private Partnership to upgrade houses within a major slum area in Yenagoa. This shall be done with an agreement between the property owners, Real Estate investors and the state government. Basic Research Methodology was applied using questionnaire, direct observation and personal interview techniques to collect data. Both qualitative and quantitative techniques were applied to analyse data through the use of tables and charts. The findings in the study showed that poor housing condition seriously degrade the environmental quality of the study area. The standard of living in the area is very poor as the people lack access to decent accommodation, basic sanitation and social amenities.
\end{abstract}

\section{Keywords}

Public-Private Partnership Arrangement, In-Situ Housing, Slum

Rehabilitation, Yenagoa, Bayelsa State, Nigeria 


\section{Introduction}

The environmental quality of cities in Nigeria is below an appreciable level where most neighbourhoods are characterized by poor housing conditions generally described as slums. "Slums are an integral part of urban landscape as they have historically been the only affordable housing available to the urban poor" [1]. According to [2], one third of urban population in the developing countries today lack adequate housing, safe water and sanitation. It has been noted [3] that slum dwellers live in overcrowded and un-serviced neighbourhoods which are often situated on marginal and dangerous land. "Over 880 million urban residents are estimated to live in slum conditions today, compared to 792 million reported in 2000 and 689 million in 1990", [4] [5] [6] attributed several environmental problems in urban centres of developing nations to poor housing conditions.

Yenagoa, the capital of Bayelsa State of Nigeria which was created on the 1st of October, 1996 is not an exception. It has been observed [7] that Yenagoa lacks affordable housing and basic sanitation due to indiscriminate housing development. The population of the city increases on daily basis due to the constant influx of people into Yenagoa immediately the town was designated as the capital of Bayelsa State. There are several environmental problems in Yenagoa due to poor housing conditions which are generally termed as slum conditions in all neighbourhoods of the city. The primary aim of the study is to show how Public-Private Partnership Mechanism of In-situ Housing for slum rehabilitation can be applied to improve housing condition in Yenagoa.

\section{Description of the Study Area}

The study was carried out within a major slum area in the central part of the city of Yenagoa in Bayelsa state. The area is bounded by Yenagoa-Mbiama Road in the North, Harbour Road in the west, Yenagoa-Oporoma Road in the South, and Obele Road in the East and has total land area of about 55.721 hectres $(0.55721$ sq. km), Figure 1 . The state capital territory lies between latitude $4^{\circ} 55^{\prime} \mathrm{N}$ and $4^{\circ} 57^{\prime} \mathrm{N}$; and longitude $6^{\circ} 16^{\prime} \mathrm{E}$ and $6^{\circ} 18^{\prime} \mathrm{E}$, Figure 1 . Yenagoa Local Government Area had a population of 151,298 persons in 1991, the total area is $706 \mathrm{~km}^{2}$ and the population density was 214 persons per square kilometre, [8]. In 2006, the figure increased to about 266,008 persons and the population density was 376 persons per $\mathrm{km}^{2}$ [9]. Yenagoa had a linear pattern of settlement as at the time Bayelsa State was created. Presently, the original settlement pattern has changed with indiscriminate construction of houses without adequate basic sanitary services within and several kilometres beyond the native villages due to rapid increase in population.

Rainfall is heavy in Yenagoa and lasts for eight to nine months (March to November) of the year with highest rainfall values obtained in the months of June (322.92 mm), July (413.59 mm), August (438.34 mm) and September (439.84 $\mathrm{mm}$ ) while the mean annual rainfall is $3191 \mathrm{~mm}$ [10]. Even the dry season 


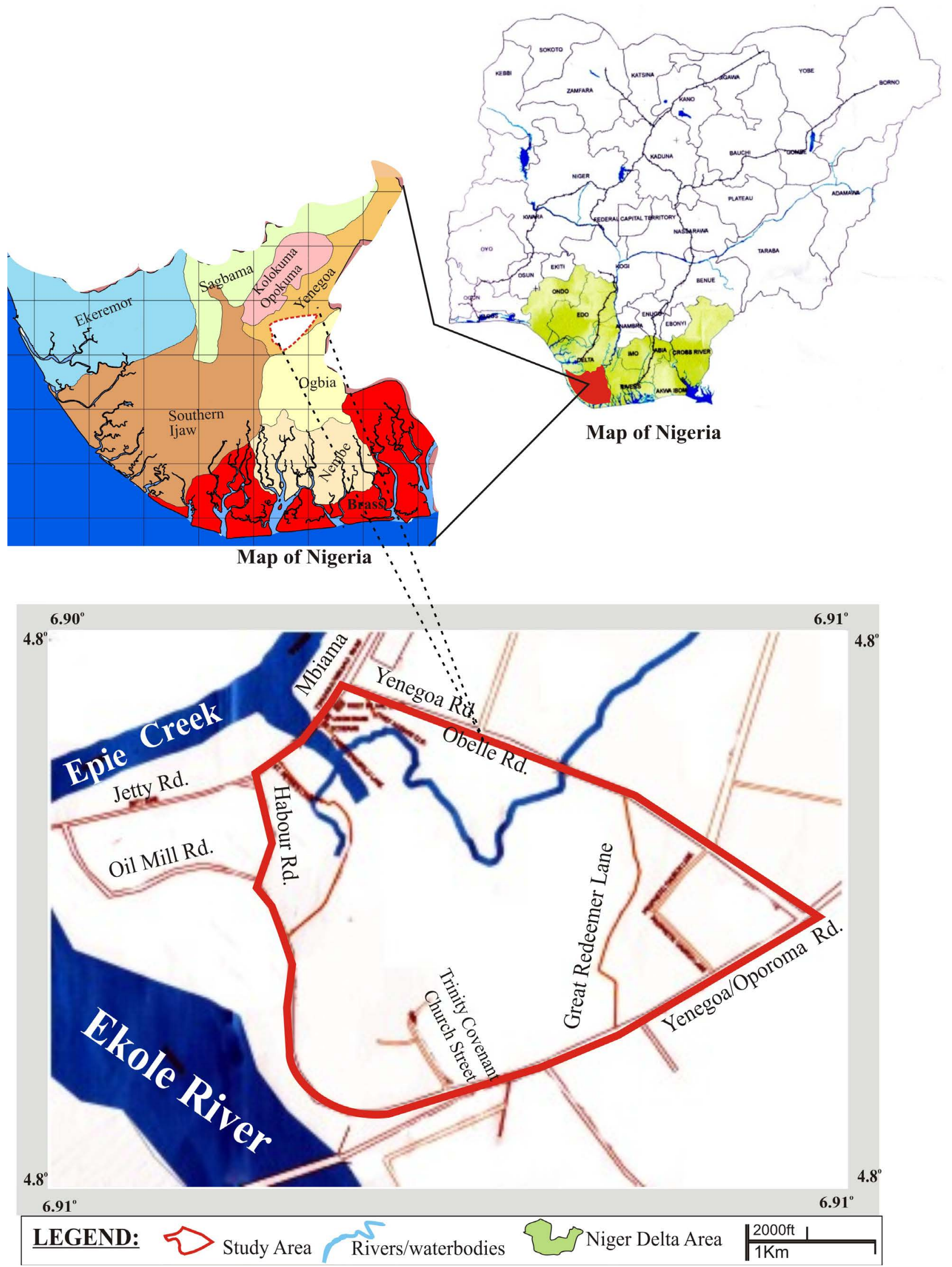

Figure 1. Map of the study area. 
months of December, January and February are not free from occasional rainfall. Due to the low terrain, swamps, high rainfall and other unfavourable climatic factors, most parts of Yenagoa are flooded for about 8 or 9 months of the year especially during the flood season from the months of May to October. It is very expensive to build a decent house in Yenagoa as it requires land reclamation and sand-filling up to 6 - 8 courses to achieve damp-poof course (D.P.C.) above annual flood level.

\section{Methodology}

The research design for the study is Basic Research methodology using questionnaire for data collection. The data collection techniques include questionnaire administration and retrieval, observation of physical environmental conditions and personal interviews. The respondents in the study are household heads in the area. Personal interviews were also conducted to gather data from government officials and community leaders. All houses in the area are considered as the population for the study. Sample frame was prepared comprising all roads and houses in the area. There are 62 roads in the area and the total number of houses is 1752 . On each of the roads, $25 \%$ of the houses were selected for assessment giving a sample size of 438 from which one household head was picked as a respondent for the study. Simple random sampling technique was applied to pick one out of the first two houses on each road in the sampling frame as starting point. Subsequently, systematic sampling method was used to pick houses for the study with a fixed periodic interval of 4 on each of the 62 roads. Both qualitative and quantitative data analysis techniques were used to interpret and explain the personal characteristics of household heads, condition of housing and sanitary services in the study area. These are analysed (described) through the use of statistical tools such as tables and charts.

\section{Results}

\subsection{Personal Characteristics of Household Heads}

Table 1 shows the age/sex characteristics of household members in the study area. The results show that there is high dependency ratio of $96 \%$ in the area which is even higher than the $88.2 \%$ dependency ratio of Nigeria [7]. This implies that there is high financial pressure on household heads in the area to provide for the dependants representing $45 \%$ of the household members less than 15 years and $3 \%$ above 64 years. It is also indicated in studies that most people between 15 and 20 years who are in school and the unemployed in the workforce depend on the few persons that are employed. The implication of the above findings of the study is that residents of the area cannot save adequate funds to afford decent accommodation due to the high financial stress on household heads created by high dependency ratio. This is one of the factors responsible for poor housing pattern/standard in the area since the people lack access to housing finance [11]. The results on occupation and income level of household heads 
Table 1. Age/sex structure of household members.

\begin{tabular}{ccccccc}
\hline \multirow{2}{*}{ Age (Years) } & \multicolumn{3}{c}{ Male } & \multicolumn{3}{c}{ Femal } \\
\cline { 2 - 7 } & No. & $\%$ & No & $\%$ & No & $\%$ \\
\hline $0-4$ & 199 & 9.00 & 240 & 11.00 & 728 & 20.00 \\
$5-9$ & 137 & 6.18 & 196 & 9.00 & 553 & 15.18 \\
$10-14$ & 109 & 5.00 & 132 & 6.00 & 401 & 11.00 \\
$15-19$ & 92 & 4.20 & 110 & 4.99 & 335 & 9.19 \\
$20-24$ & 88 & 4.00 & 91 & 4.00 & 292 & 8.00 \\
$25-29$ & 72 & 3.29 & 88 & 4.00 & 266 & 7.29 \\
$30-34$ & 55 & 2.53 & 87 & 4.00 & 238 & 6.53 \\
$35-39$ & 49 & 2.23 & 66 & 2.99 & 191 & 5.22 \\
$40-44$ & 35 & 1.58 & 66 & 2.99 & 167 & 4.57 \\
$45-49$ & 27 & 1.23 & 44 & 2.00 & 118 & 3.23 \\
$50-54$ & 22 & 1.00 & 44 & 2.00 & 109 & 3.00 \\
$55-59$ & 22 & 1.00 & 25 & 1.15 & 78 & 2.15 \\
$60-64$ & 13 & 0.59 & 22 & 0.98 & 58 & 1.57 \\
$65+$ & 22 & 1.00 & 44 & 2.00 & 109 & 3.00 \\
TOTAL & 942 & 43.00 & 1255 & 57.00 & 2197 & 100.00 \\
\hline
\end{tabular}

shown on Table 2 is an indication that most residents of the area live below the United Nations approved poverty line of one dollar a day. The table shows that $35 \%$ of the household heads in the area have an income of less than N100,000.00 per annum while none have an income of above N1,000,000.00 per annum. This also conforms to the 2015 Report on goal 1 of the Millennium Development Goals (MDGs) that $14 \%$ of the population of the developing world still live on less than $\$ 1.25$ a day even though it was nearly $50 \%$ in 1990 . It is an indication that most of the residents could not afford house rent in decent neighbourhoods or build personal houses due to low income.

\subsection{Building Pattern/Standard}

Figure 2 shows building pattern /standard in the study area. The results on the figure show that most of the houses in the area are in deplorable physical condition. Despite the fact that most of the houses are only a few years old, they are in poor physical condition due to lack of building maintenance. It implies that the people are exposed to several health problems associated with poor housing conditions as identified by [12]. The results on Table 3 show that $32 \%$ of the 438 houses are built with temporary building materials. The above findings confirm that most of the houses in the area are only a few years old but in deplorable physical condition either due to the use of substandard building materials or lack of maintenance which was also noted by [13]. The findings on Figure 3 show that only $2 \%$ of the houses in the area are 3 or more metres from other houses while the rest $98 \%$ are less than 3 metres from one another. This shows that 
Table 2. Occupation/income level.

\begin{tabular}{|c|c|c|c|c|c|c|c|c|c|c|}
\hline \multirow{3}{*}{ Occupation } & \multirow{2}{*}{\multicolumn{2}{|c|}{$\begin{array}{c}\text { Less than } \\
\mathrm{N} 100,000.00\end{array}$}} & \multirow{2}{*}{\multicolumn{2}{|c|}{$\begin{array}{l}\mathrm{N} 101,000.00 \\
\mathrm{~N} 500,000.00\end{array}$}} & \multirow{2}{*}{\multicolumn{2}{|c|}{$\begin{array}{c}\text { N501,000.00 } \\
\text { N1000,000.00 }\end{array}$}} & \multirow{2}{*}{\multicolumn{2}{|c|}{$\frac{\text { Above }}{\text { N1000,000.00 }}$}} & \multirow{2}{*}{\multicolumn{2}{|c|}{ Total }} \\
\hline & & & & & & & & & & \\
\hline & No. & $\%$ & No. & $\%$ & No. & $\%$ & No. & $\%$ & No. & $\%$ \\
\hline Farming & 4 & 1 & & & & & & & 4 & 1 \\
\hline Crafts & & & 18 & 4 & & & & & 18 & 4 \\
\hline Trading & 22 & 5 & 70 & 16 & 9 & 2 & & & 101 & 23 \\
\hline Civil servant & 226 & 6 & 35 & 8 & & & & & 61 & 14 \\
\hline \multicolumn{11}{|c|}{ Companyemployee } \\
\hline $\begin{array}{l}\text { Self employed } \\
\text { (business) }\end{array}$ & 101 & 23 & 153 & 35 & & & & & 254 & 58 \\
\hline Total & 153 & 35 & 276 & 63 & 9 & 2 & & & 438 & 100 \\
\hline
\end{tabular}

Table 3. Description of houses under study.

\begin{tabular}{|c|c|c|c|}
\hline S/No. & Description of House & No & $\%$ \\
\hline 1) & $\begin{array}{l}\text { Thatch house (mud wall, thatch roof, not concrete floor, } \\
\text { wooden windows, no ceiling) }\end{array}$ & - & - \\
\hline 2) & $\begin{array}{l}\text { Temporary structure (wooden/zinc wall, zinc roof, } \\
\text { concrete floor, wooden windows, no ceiling) }\end{array}$ & 140 & 32 \\
\hline 3) & $\begin{array}{l}\text { Mud house not plastered, zinc roof, } \\
\text { concrete floor, wooden windows, ceiled }\end{array}$ & 26 & 6 \\
\hline 4) & $\begin{array}{l}\text { Mud house plastered, zinc roof, } \\
\text { concrete floor, wooden window, not painted, ceiled. }\end{array}$ & 13 & 3 \\
\hline 5) & Mud house plastered, zinc roof, concrete floor, wooden window, painted & 53 & 12 \\
\hline 6) & $\begin{array}{l}\text { Block wall, zinc/corrugated iron sheets roof, concrete floor, } \\
\text { louver/glass windows, unpainted wall, ceiled. }\end{array}$ & 127 & 29 \\
\hline \multirow[t]{2}{*}{ 7) } & $\begin{array}{l}\text { Block wall, zinc/corrugated iron sheets roof, concrete wall, } \\
\text { louver/glass windows, painted wall, ceiled. }\end{array}$ & 79 & 18 \\
\hline & Total & 438 & 100 \\
\hline
\end{tabular}

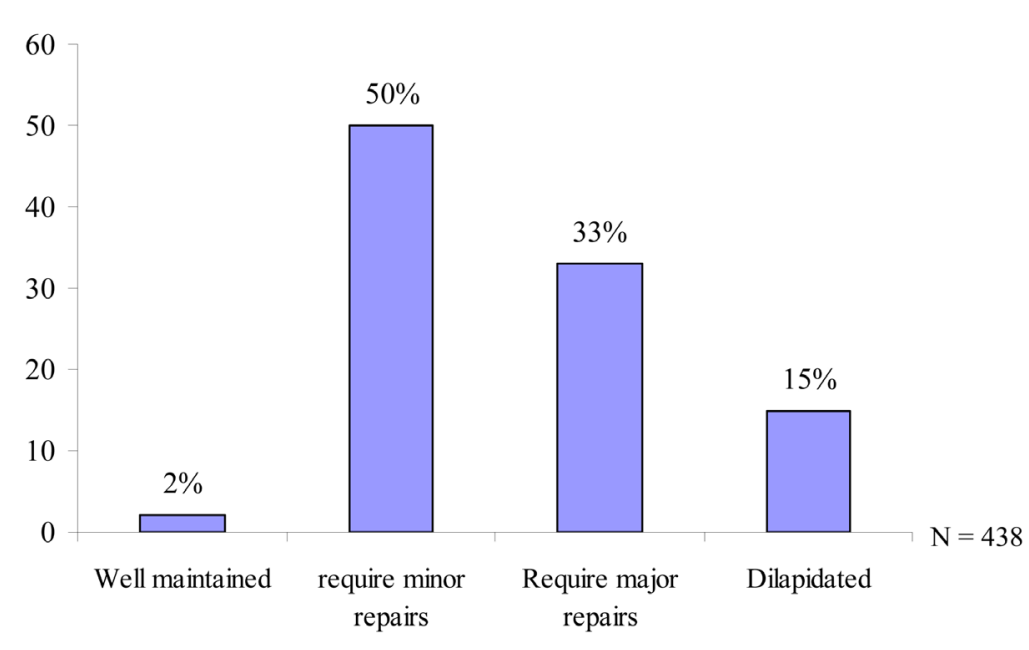

Figure 2. Building pattern/standard (maintenance). 


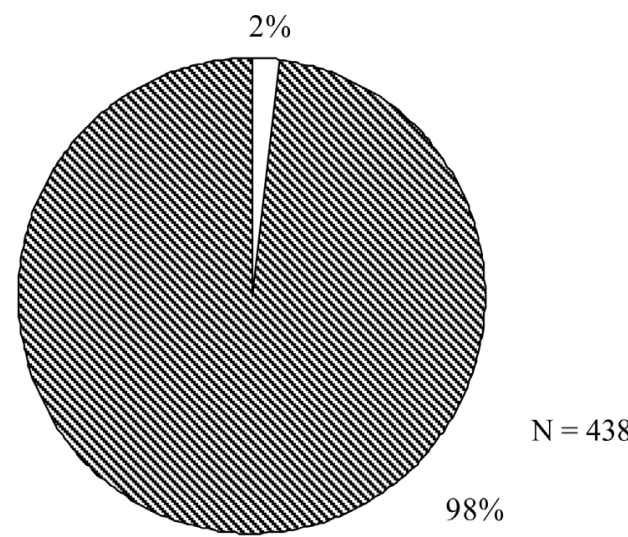

$\square$ Three or more metres from other houses

Less than three metres from other houses

Figure 3. Building density (distance between houses) by community.

houses in the area are overcrowded due to haphazard building operations without adequate air spaces between houses. Despite the existing laws to regulate building operations in Yenagoa, developers in the area build houses without adequate setback or open space for ventilation and outdoor activities as also identified in Port Harcourt [14]. This is a serious environmental challenge to the residents of the area and other parts of Nigeria as people in high density neighbourhoods use streets for outdoor activities like football, wedding and burial parties among others. It was identified in the study that most houses in the study area are poorly positioned with most of them facing the back or sides of other houses without adequate air space. In a well-planned settlement, the building pattern is regulated in a manner that houses either face each other or face the back or sides of other houses with adequate space apart. The residents of the study area are prone to several environmental problems like odour and unsightliness occasioned by inadequate airspace between houses that led to the formation of stagnant domestic waste water directly in front of houses that constitute nuisance.

The results on Table 4 show that $96 \%$ of the households in the area have an occupancy rate of five or more persons per room. While the results on Table 3 also show that $74 \%$ of the households have household size of five or more persons. The above findings show that the area is not only overcrowded with houses but also with people as there is high occupancy rate of five or more persons livin in a room. The above findings are indications that the health of the residents of the area is at risk. There are several diseases and health hazards that are created by the unhealthy buildings and unsanitary living environment [6].

\subsection{Type and Use of Toilet}

Figure 4 shows type of toilet being used in the study area. The results show that only $27 \%$ (118) of the households in the area have water closet (wc) toilet while 
Table 4. Occupancy rate (persons per room).

\begin{tabular}{|c|c|c|c|c|c|c|c|c|c|c|c|c|c|c|c|c|}
\hline \multirow{2}{*}{ Settlement } & \multicolumn{2}{|c|}{01} & \multicolumn{2}{|c|}{02} & \multicolumn{2}{|c|}{03} & \multicolumn{2}{|c|}{04} & \multicolumn{2}{|c|}{05} & \multicolumn{2}{|c|}{06} & \multicolumn{2}{|c|}{07} & \multirow{2}{*}{ No } & \multirow{2}{*}{$\%$} \\
\hline & No & $\%$ & No & $\%$ & No & $\%$ & No & $\%$ & No & $\%$ & No & $\%$ & No & $\%$ & & \\
\hline Obele & - & - & - & - & - & - & 5 & 1 & 60 & 14 & 58 & 13 & 48 & 11 & 171 & 39 \\
\hline Ololo & - & - & - & - & - & - & - & - & 43 & 10 & 44 & 10 & 39 & 9 & 126 & 29 \\
\hline Igugu & - & - & 4 & 1 & 4 & 1 & 4 & 1 & 45 & 10 & 47 & 11 & 37 & 8 & 141 & 32 \\
\hline Total & - & - & 4 & 1 & 4 & 1 & 9 & 2 & 148 & 34 & 149 & 34 & 124 & 28 & 438 & 100 \\
\hline
\end{tabular}

Rating: (01-One person per room); (02-Two persons per room); (03-Three persons per room); (04-Four persons per room); (05-Five persons per room); (06-Six persons per room); (07-Seven or more persons per room).

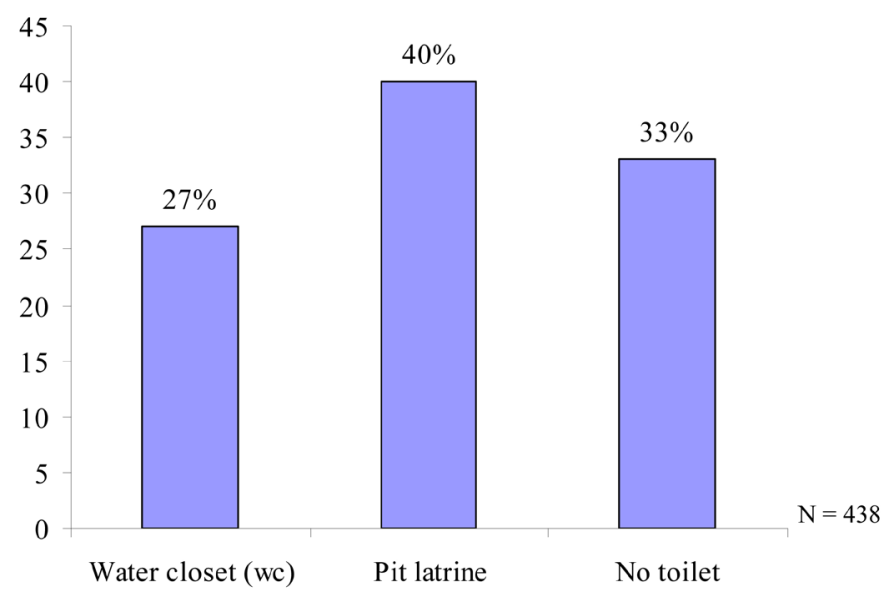

Figure 4. Type of toilet.

the rest $73 \%$ (320) either use environmentally-unfriendly types of toilet or without toilet. The study further shows that $36 \%$ (42) of the 118 households that use wc toilet pipe them to seasonal streams. This shows that the area lacks basic sanitation as the soil as well as water resources are polluted with human faeces which also expose the residents to health risk [15]. The study also shows that only $8 \%$ of the 118 households that use wc toilet exclusively use their toilet facilities. It implies that the people lack basic sanitation as most of the houses in the area were built without toilet [16]. The results on Figure 5 show that the environmental quality of Yenagoa is very poor in terms of sewage management. The results show that only $14 \%$ of the 118 houses with water closet toilet have well-maintained septic tanks while $36 \%$ of the water closet (wc) toilets are piped into seasonal streams. The above findings are indications that residents of the area are prone to environmental problems that create health challenges in the area. The implication is that the residents are exposed to several environmental hazards and diseases like cholera, dysentery and skin infection amongst others which conforms to earlier study [17].

\subsection{Roads}

The findings of the study show that the condition of roads in the area is bad. The 


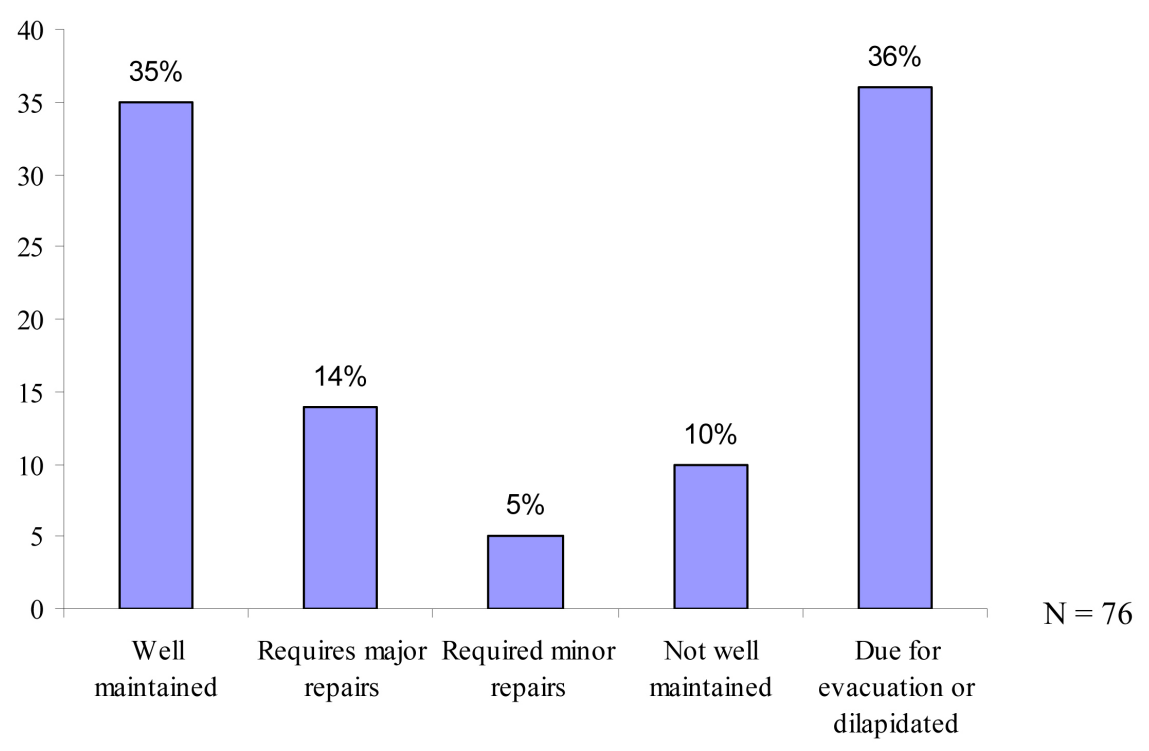

Figure 5. Condition of sewage disposal system (septic tank).

results show that only $10 \%$ of the houses are along tarred roads of 11 or more metres right-of-way without pothole, $3 \%$ are on tarred roads of $10-10.9$ metres right-of-way with potholes while the rest $87 \%$ are either along tarred narrow roads of less than 10 metres right-of-way, un-tarred roads or not accessible with vehicle, Figure 6. This shows that the area lacks functional access roads. This is responsible for problems like transportation of building materials and traffic congestion in the area as car owners pack on the few roads which are even far from their houses among other problems also identified by previous studies [18]. The findings of the study further show that none of the houses in the area is along any road with covered flowing drainage system. The study identified lack of land-use planning and inadequate provision of functional drainage system as the cause of flooding in Yenagoa. The findings of the study also show that only $10 \%$ of the households in the area sorted solid wastes before packing them into special sanitation bags while the rest $90 \%$ apply environmentally-unfriendly solid waste management methods where $28 \%$ of the households even dump solid wastes either behind buildings, by road-side or into seasonal streams. The area also lacks waste collection facilities and the few central waste collection centres are not evacuated on daily basis. This shows that the residents are exposed to health and environmental problems due to lack of basic sanitation [19] [20].

\section{Conclusion and Recommendations}

The study showed that poor housing quality in the area is attributable to many factors but high dependency ratio, low income of residents and high occupancy rate are prominent. This shows that living standard of the people is very poor. The houses are overcrowded, poorly maintained and the area lacks improved basic sanitation facilities. This is at variance with the Sustainable Development Goals (SDGs) 11 which is to make cities and human settlements inclusive, safe, 


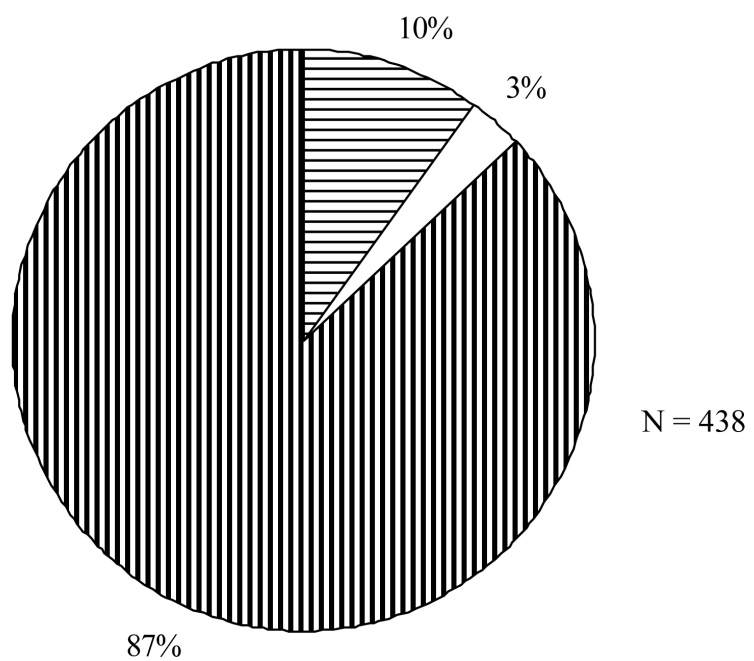

$\boxminus$ Tarred road of 11 or more metres right of way and without pothole

$\square$ Tarred road of 10-10.9 metres right of way and without pothole

W Tarred road of less than 10 metres right of way un-tarred acess road

Figure 6. Conditions of roads by community.

resilient and sustainable. It is recommended that a Public-Private Partnership Arrangement of In-situ Housing for Slum Rehabilitation be adopted to upgrade housing in the area. This shall be done through an agreement between the property owners, real estate investors and Bayelsa State Government using a Comprehensive Slum Rehabilitation Scheme.

\section{Acknowledgements}

The platform for this study was provided by the Institute of Geosciences and Space Technology (IGST), Rivers State University, Port Harcourt, Nigeria to whom the authors are grateful.

\section{References}

[1] Andavarapu, D. and Edelman, D.J. (2013) Evolution of Slum Redevelopment Policy. Current Urban Studies, 1, 185-192. https://doi.org/10.4236/cus.2013.14021

[2] UN-Habitat (2010) Development Context and the Millennium Agenda. The Challenge of Slums: Global Report on Human Settlements, 1-23.

[3] Sorate, R.R., Dhiman, A., Murnal, A., Nimbalkar, M., Dere, N. and Tiwari, V. (2014) Slum Rehabilitation with Fast Track Techniques. IOSR Journal of Mechanical and Civil Engineering (IOSR-JMCE), 11, 27-32.

[4] United Nations (2015) Millennium Development Goals Report 2015. United Nations, New York, 60-61.

[5] United Nations (2015) The Sustainable Development Goals Report 2016. United Nations, New York, 32-33.

[6] Agbola, T., Nwokoro, I. and Kassim, F.F. (2016) Housing and Health. In: Agbola, T., Egunjobi, L. and Olatubara, C.O., Eds., Housing Development and Management, Artsmostfare Prints, Ibadan, 503-535. 
[7] Federal Republic of Nigeria (2009) National Bureau of Statistics. Annual Abstract of Statistics, 62-99.

[8] Federal Republic of Nigeria (1991) The Analytical Report on the Population Census of the Federal Republic of Nigeria. $455 \mathrm{p}$.

[9] Federal Republic of Nigeria (2009) Legal Notice on Publication of 2006 Census Final Results. Official Gazette No. 2, Vol. 96, B1-42.

[10] Government of Bayelsa State of Nigeria (2004) Yenagoa Maser Plan. Harcourt Aduke Associates, Port Harcourt, 6-7.

[11] Alabi, M. (2016) Housing Finance. In: Agbola, T., Egunjobi, L. and Olatubara, C.O., Eds., Housing Development and Management, A Book of Readings, Artsmostfare Prints, Ibadan, 781-799.

[12] Olatubara, C.O. and Adegoke, S.A.O. (2016) Housing Maintenance. In: Agbola, T., Egunjobi, L. and Olatubara, C.O., Eds., Housing Development and Management, A Book of Readings, Artsmostfare Prints, Ibadan, 407-429.

[13] Ifesanya, A.O. (2016) Building Materials Production and Use. In: Agbola, T., Egunjobi, L. and Olatubara, C.O., Eds., Housing Development and Management, A Book of Readings, Artsmostfare Prints, Ibadan, 335-367.

[14] Nnah, W.W., Owei, O.B. and Ikpoki, M.I. (2007) Development Control and the Public Interest in Obio-Akpor Local Government Area of Rivers State, Nigeria. Journal of the Nigerian Institute of Town Planners, 20, 71-86.

[15] Agbola, T. and Kassim, O.F. (2016) Conceptual and Theoretical Issues in Housing. In: Agbola, T., Egunjobi, L. and Olatubara, C.O., Eds., Housing Development and Management, A Book of Readings, Artsmostfare Prints, Ibadan, 19-86.

[16] Simiyu, S. (2015) Determinant of Usage of Communal Sanitation Facilities in Informal Settlements of Kisumu, Kenya. Environment \& Urbanization, International Institute for Environment and Development (IIED) Sapepublication, Stellenbosch, $19 \mathrm{p}$.

[17] Enger, E.D. and Smith, B.F. (2004) Environmental Science: A Study of Interrelationships. McGraw-Hill Companies Inc., New-York. 280-304.

[18] Obateru, O.I. (2003) Land Subdivision Basics. Penthouse Publications, Ibadan, 139 p.

[19] Schaefer, R.T. (2003) Eighth Edition Sociology. McGraw-Hill Companies Inc., New York, 504-507.

[20] Bradshaw, M., White, G.W. and Dymond, J.P. (2004) World Regional Geography. Global Connections, Local Voices. McGraw-Hill Companies, Inc., New York. 